\title{
Репродукція як один із факторів стійкості популяцій рідкісних видів рослин
}

Проведено дослідження репродукції семи видів рідкісних рослин (Epipactis helleborine, Listera ovata, Platanthera chlorantha, Circaea alpine, Lilium martagon, Pulsatilla patens i Pyrola chlorantha) в умовах НПП «Деснянсько-Старогутський». Найменший внесок у репродукцію характерний для Lilium martagon, а найбільший Pulsatilla patens.

Ключові слова: рідкісні види, репродукція, репродуктивне зусилля, неруйнуючі методи, морфометрія.

Постановка наукової проблеми та ії значення. Для популяцій рослин властивий потік поколінь, які постійно змінюються в часі. Ця змінність визначається простим співвідношенням

$$
\mathrm{N}=\mathrm{b}-\mathrm{d},
$$

де $\mathrm{N}$ - чисельність рослин у популяції, $\mathrm{b}$ - народжуваність і d - смертність.

Народжуваність у світі рослин визначається рівнем репродуктивного процесу, який, згідно 3 Ю. А. Злобіним [7], уключає такі компоненти, як формування квіток, запилення й запліднення, утворення насіння та плодів, дисперсія. Їх реалізація визначається внеском матеріально-енергетичних ресурсів у репродукцію, тобто величиною репродуктивного зусилля. Для популяцій рідкісних видів рослин здійснення репродуктивного процесу часто виступає як критичний фактор через неповну відповідність еколого-фітоценотичних умов місцезростання екологічному оптимуму цього виду рослин і малій чисельності особин у популяціях. Багато видів рідкісних рослин охороняється законодавством України [23] і тому вивчення особливостей та можливих вразливостей репродуктивного процесу в цієї групи рослин $є$ актуальною науковою проблемою. Протягом вегетаційних періодів 2009-2014 рр. ми вивчали репродукцію семи видів рідкісних рослин (Circaea alpina L., Epipactis helleborine (L.) Crantz., Lilium martagon L., Listera ovata (L.) R. Br., Platanthera chlorantha (Cust.) Rchb., Pulsatilla patens (L.) Mill., Pyrola chlorantha Sw.) в умовах Національного природного парку «Деснянсько-Старогутський» (НППДС).

Аналіз досліджень цієї проблеми. Репродуктивному процесу в рідкісних видів рослин до останнього часу дослідники приділяли мало уваги. Найбільш дослідженою виявилася репродукція в представників родини Orchidaceae, стосовно яких висвітлена роль комах, що спеціалізовані на запиленні цих видів рослин $[4,25,26,27]$, а також відсутність у представників цієї родини стійкого грунтового банку насіння [20]. Дані щодо репродукції рідкісних видів рослин із родин Liliaceae, Pyrolaceae, Onagraceae i Ranunculaceae одиничні й не відтворюють повної картини репродуктивного процесу в представників цих родин [1, 18, 16 і деякі ін.].

Мета й завдання статті. Для виконання дослідження використовували загальноприйняті методи геоботаніки й популяційної екології рослин $[6,8,11,21]$. Використовували марковані особини та неруйнуючі методи аналізу репродукції [17]. При визначенні репродуктивного зусилля рослин використовували відношення кількісних показників до площі листової поверхні. Роботу проведено в період із 2009 до 2014 р. Усього дослідженнями охоплено понад 700 особин рідкісних видів рослин.

Виклад основного матеріалу й обгрунтування отриманих результатів дослідження. На основі трирічних досліджень установлено основні особливості репродукції в досліджуваної групи рідкісних видів рослин і виявлено фактори, які можуть бути критичними для їх ефективної репродукції. Дані, що характеризують кількісні параметри репродукції досліджуваних видів рідкісних рослин, відображено в табл. 1.

Epipactis helleborine. Суцвіття - однобока китиця. Кількість квіток у ній - від 12 до 50, а іноді й більше [10]. Основні запилювачі - це оси роду Dolichovespula. Відвідують квіти й інші комахи, але вони не $\epsilon$ ефективними запилювачами. Спостерігається гейтономогамія, коли часто пилок переноситься на квітки в межах одного суцвіття. Нектар містить етанол і на комах діє п'янким запахом, позбавляючи їх на деякий час рухливості [25]. Плід - коробочка, що містить до 3-4,5 тис. шт. насіння. Одна рослина продукує таким чином до 40-60 тис. шт. насіння. Проростки протягом кількох років ведуть підземний спосіб життя.

(C) Клименко Г., Коваленко I., 2016 
Показники репродуктивної сфери для рідкісних рослин

\begin{tabular}{|c|c|c|c|}
\hline Вид & ПНП, $\mathbf{u m}$ & $\mathbf{\Phi H \Pi , ~} \boldsymbol{u m}$ & RE, \% \\
\hline Circaea alpina (П1) & $14,93 \pm 1,050$ & - & $36,56 \pm 2,226$ \\
\hline Circaea alpine (П2) & $28,44 \pm 2,409$ & - & $45,31 \pm 4,716$ \\
\hline Epipactis helleborine & $10,38 \pm 0,908$ & $0,79 \pm 0,576$ & $10,67 \pm 0,961$ \\
\hline Lilium martagon & $6,06 \pm 0,345$ & $2,34 \pm 0,355$ & $1,05 \pm 0,061$ \\
\hline Listera ovate & $30,94 \pm 0,896$ & $22,06 \pm 1,719$ & $30,15 \pm 1,132$ \\
\hline Platanthera chlorantha & $19,09 \pm 0,776$ & $13,35 \pm 0,898$ & $14,29 \pm 0,935$ \\
\hline Pulsatilla patens (П1) & $536,11 \pm 60,613$ & $346,80 \pm 39,209$ & $250,36 \pm 36,526$ \\
\hline Pulsatilla patens (П2) & $523,21 \pm 137,066$ & $338,45 \pm 88,665$ & $499,06 \pm 261,31$ \\
\hline Pulsatilla patens (П3) & $472,49 \pm 34,008$ & $305,64 \pm 21,999$ & $53,81 \pm 5,885$ \\
\hline Pulsatilla patens (П4) & $283,78 \pm 27,092$ & $191,22 \pm 14,858$ & $205,96 \pm 34,289$ \\
\hline Pulsatilla patens(П5) & $288,21 \pm 28,178$ & $156,45 \pm 23,322$ & $103,35 \pm 33,993$ \\
\hline Pyrola chlorantha & $5,28 \pm 0,190$ & $2,87 \pm 0,251$ & $32,92 \pm 4,111$ \\
\hline
\end{tabular}

Примітка. ПНП - потенційна насіннєва продуктивність, ФНП - фактична насіннєва продуктивність, RE репродуктивне зусилля.

В умовах НППДС генеративні особини E. helleborine мали від 5 до 26 квіток у суцвітті, при цьому вихід повноцінних плодів на одній рослині в середньому був не більше одного плода на рослину. За даними Н. П. Стецук [19], у Південному Приураллі плодозав'язуваність цього виду була на рівні 38 56 \%, однак відзначено пошкодження рослин фітофагами. В умовах НППДС спостерігали суцільне засихання генеративних рослин після утворення бутонів, таким чином більшість рослин навіть не доходили до цвітіння. Відсоток квітучих рослин був на невисокому рівні й щорічно змінювався. Відзначається нерівномірність цвітіння рослин цього виду, при цьому перерва в цвітінні може бути 1, 2 і навіть три роки.

Listera ovata. Суцвіття - китиця 3 дрібних жовто-зелених квіток (до 40 і більше). Цвітіння особини зазвичай триває довго, понад місяць. За даними І. В. Блінової [2], на північній межі розповсюдження період плодозав'язування продовжується до 42 днів. Відсоток зав'язування плодів досить високий, 37-66 \%. Але при цьому в популяціях, зазвичай, майже немає проростків і ювенільних рослин [3]. Дарвін розглядав квіти цієї рослини як екологічно примітивні в межах родини Orchidaceae, оскільки вони не мають вираженої спеціалізації в запиленні комахами [21]. Коло комах-запилювачів широке. У полініїв немає ніжки, тому вони кріпляться напряму до тіла комахи. Плоди - коробочки, кількість насіння в одній із них - до 6 тис. шт. [13]. Плодоутворення високе (часто понад 90 \%) i зазвичай не пов'язане $з$ дефіцитом запилювачів, воно більше залежить від стійких періодів сухої погоди без дощів $[4,28]$. Після проростання насіння надземний пагін з'являється тільки на 4-й рік.

На рівні окремих особин у досліджуваній популяції $L$. ovata за три роки спостережень мінімальне значення насіннєвої продуктивності перебувало в межах 10-15 генеративних структур на одну особину, а максимальне - 55 генеративних структур на особину. Фактична мінімальна насіннєва продуктивність у роки досліджень також була схожою: у 2009 р. вона складала один й у 2010-му шість плодів на особину. Максимальна фактична насіннєва продуктивність дорівнювала, по роках, 45 і 55 плодів на особину у 2009-му й 2010 рр., відповідно. У цілому можна говорити про досить сприятливі умови зростання для цього виду, адже рослина формує в середньому 30 плодів, із яких 22 виповнені. Аналогічні результати отримані при дослідженні популяцій цього виду в межах Брянської області Російської Федерації [22].

Platanthera chlorantha. Суцвіття містить 10-40 квіток. Пиляки із широким зв'язником і гніздами, які дуже сильно розходяться і розставлені; відстань між гніздами пиляка зверху - до 1,5 мм, знизу - до 4 мм.

Квітки пахучі, запах посилюється вночі. Запилювачі - переважно нічні й сутінкові метелики. Усього зареєстровано до 30 видів запилювачів. При відвідуванні квітки пилок потрапляє прямо на очі комахи-запилювача [21]. Для генеративних особин характерні перерви у цвітінні тривалістю у $2-$ 5 років [4]. Плоди - коробочки, що розкриваються вузькими щілинами. Рослина - анемохор. Плодозав'язуваність досягає від 25 до 70-90 \% [25]. Проростки 2-4 роки ведуть підземний спосіб життя, для них необхідні гриби-мікоризоутворювачі. Квітують рослини на 9-11 році життя. 
В умовах НППДС рослини мали показники репродуктивної сфери з максимальною кількістю квіток до 42 шт. у суцвітті. За роками відзначали поступове зниження середньої кількості квіток на рослину (із 21,23 до 16,50 в.). Фактична плодозав'язуваність сягала 13,35 виповнених плодів на рослині. Також визначали репродуктивне зусилля для цього виду. Для розрахунку використовували кількість генеративних структур і загальну площу листової поверхні рослин. Внесок у репродукцію цього виду складав 14,29\%.

Circaea alpina. Квіти 2-вимірні білого або рожевого відтінку, актиноморфні. Пелюстки коротші за чашолистики. У C. alpina квіти спочатку протогінічні, але за відсутності перехресного запилення тичинкові нитки подовжуються та вигинаються так, що пильники прикладаються до ще чутливих рилець.

Плід - сухий горішок, не розкривається та вкритий гачкоподібними волосками. За літературними даними, насіння може зберігати схожість у грунті до п’яти років [24].

Суцвіття - рацемозна китиця, формується на верхівці і головного, і іноді й бічних пагонів. Довжина суцвіття - від одного до 17 см. Одночасно відкрито зазвичай 3-6 квіток. В. А. Верещагіна [5] встановила, що в цієї рослини простежено чітку автогамію. Самозапилення відбувається при відкритті квітки, комахи зазвичай не відвідують квітки. Виняток становлять мілкі двокрилі збирачі нектару. Плодозав'язуваність перебуває на рівні 60 \%. Плоди вкриті міцними гачкоподібними волосками, що вказує на можливість зоохорії [12].

Проведені дослідження двох популяцій $C$. alpine у межах НППДС засвідчили, що репродукційний процес цього рідкісного виду успішніше відбувається в умовах, у яких зростає популяція № 2, тобто на західному схилі борової тераси.

Успішність репродукції значною мірою залежала від здатності рослини утворювати бічні генеративні пагони й від відсотка таких рослин від усіх генеративних у популяції. Обстеження показали, що в популяції № 2 C. alpina 80 \% рослин мали бічні генеративні пагони, тоді як у популяції № 1 таких рослин було не більше $10 \%$. Показники середньої кількості бічних генеративних пагонів на рослину також відрізнялися для досліджуваних популяцій - 0,43 для П1 і 1,93 для П2. У результаті потенційна насіннєва продуктивність майже удвічі більша в популяції № $2(8,44$ насінини на одній рослині, табл. 1). Репродуктивне зусилля, яке підраховано окремо для кожної популяції виду, повторювало виявлену закономірність і мало вище значення: для П2 - 45,31 \%, тоді як для П1 репродуктивне зусилля майже на $10 \%$ було нижчим.

Lilium martagon. Рослини квітують і плодоносять на 4-5-му році життя. Суцвіття китицеподібне, у ньому формується від 5-10 і до 50 квіток. Квітки пониклі, оцвітина бруднувато-пурпурова, у середині з темно-фіолетовими плямочками. Листочки їі довгасті, тупі, загорнуті. Плоди - коробочки, змінюють орієнтацію і стоять вертикально, так що суцвіття в цій фазі нагадує канделябр. Нектарники закриті, щілиноподібні. Основними запилювачами виступають нічні й рідше - денні метелики. Плоди дозрівають у серпні-вересні. Розкриваються вони в суху погоду. Баліст має пласке насіння із плівчастими краями, розноситься вітром [15]. Схожість насіння складає 29-44\%. Проростання й формування його підземної цибулинки займає два вегетаційні періоди [9]. Формує до 100-130 шт. насінин на особину [14]. Проростання насіння підземне, проростки до року не з'являються на поверхні грунту.

В умовах НППДС генеративні рослини утворювали від двох до 11 квітів, при цьому рослини утворювали максимально шість плодів. Усереднені дані стосовно потенційного й реального плодоутворення наведено в табл. 1. Аномальним виявився 2011 р., у який квітучою відзначали лише одну рослину - L. martagon. Першочергове значення у цвітінні та плодоношенні рослин L. martagon мали умови жаркого й сухого вегетаційного періоду 2010 р., вплив яких проявився на наступний вегетаційний сезон. Зіпсовані плоди відзначали щороку, серед них були як засохлі, так і пошкоджені фітофагами коробочки. Репродуктивне зусилля цього виду, яке вираховували за співвідношенням кількості плодів до загальної листової поверхні рослини, мало значення 1,05\%. При цьому рослина розмножується переважно насінням.

Pulsatilla patens. Квітки крупні, вузькодзвоникоподібні, пониклі, актиноморфні, одинарні з численними приймочками й тичинками. Плоди - горішки з перисто-волосистими стовпчиками.

У цієї рослини яскраво виражена автокриптохорія, що виявляється в самозариванні насіння в землю. Це досягається за рахунок того, що стовпчик при плодах сильно розростається й здійснює 
вісім витків спіралі, які, розкручуючись при підвищенні вологості, забезпечують заглиблення плодів у грунт [12]. Деякі ботаніки наявність на стовпчиках плодів густого опушення розглядають як пристосування до анемохорії. Фактично ці думки не суперечливі. Насіння проростає на ділянках оголеного грунту.

На території НППДС досліджували п’ять популяцій. Результати відображено в табл. 1. В умовах парку в одній квітці утворювалось у середньому 177,36 плодиків. Рослини відрізнялися за кількістю квітів, яких нараховувалося від однієї до 15. Отже, найбільше насіння утворювалось у популяціях № 1, 2 і 3 (від 472,49 до 536,11 штук на рослину). Популяції № 4 і 5 відзначалися дещо меншими показниками насіннєвої продуктивності - близько 283 насінин на рослину. Така різниця у виході насіння спостерігається через значні відмінності в кількості квітів у цих популяціях. Так, у популяціях № 1-3 рослини формували до 15 генеративних пагонів, а в популяціях № 4 і 5 максимально відзначали до п'яти генеративних пагонів на рослину. Реальна насіннєва продуктивність цього виду була на рівні 156,45-346,80 насінин на рослину.

Репродуктивне зусилля визначали окремо для кожної популяції виду. Результати представлені в табл. 1. Для $P$. patens репродуктивне зусилля перевищує $100 \%$ і навіть сягає 499,06 \% для популяції № 2. У популяції № 3 цей показник був на рівні $50 \%$. Тут спостерігаємо значне наростання маси листя, адже саме в цій популяції значний відсоток квітів, пошкоджених фітофагами або з'їдених тваринами, найімовірніше лосями. У такому пошкодженому стані на початку вегетації рослини збільшують внесок у формування листя, кількість якого в окремих випадках сягає 150-170 штук на особину. На основі проведених досліджень можна зробити висновок про те, що найвищою успішністю репродукційного процесу відзначалися популяції № 1-3, тоді як у № 4 і 5 показники потенційної і реальної насіннєвої продуктивності були знижені майже удвічі. Відповідно до значень репродуктивного зусилля, найбільше енергії на свою репродукцію витрачали рослини в популяціях № 2,1 i 4.

Pyrola chlorantha - вічнозелена рослина. Суцвіття - китиця, що має довжину до 7 см, із невеликою кількістю квітів. Квітки актиноморфні. Пиляки з ріжками, зеленувато-жовті. Зав'язь із вигнутим стовпчиком 6-7 мм завдовжки, що виступає з віночка. Плоди - коробочки. Вони зазвичай звисають донизу, що при розгойдуванні на повітрі забезпечує кращу дисперсію насіння [12]. Зазвичай дозріває 1-4 коробочки на особину.

У межах України досліджувана популяція P. chlorantha є крайнім північним локалітетом. Генеративні пагони в середньому сягають 14 см заввишки. Суцвіття рідкоквіткове, утворює від восьми до 10 квіток. Середньорічні показники фактичної й потенційної насіннєвої продуктивності були стабільними за роками. Вихід виповнених плодів на рослину також не варіював за роками і становив у середньому 2,8 коробочки на рослину (табл. 1). Репродуктивне зусилля цього виду перебуває на досить високому рівні й складає 32,92 \%. Отже, показники репродуктивної сфери у досліджуваного рідкісного виду $P$. chlorantha мали досить стабільні значення. Змінювалася лише кількість генеративних рослин у популяції за роками.

Висновки та перспективи подальшого дослідження. Установили, що найбільш успішною в репродукції виявилася Pulsatilla patens. Репродуктивне зусилля цього виду сягало майже $500 \%$, адже Pulsatilla patens розмножується переважно насінням. Найменший внесок у репродукцію характерний для Lilium martagon (1,05\%), серед трьох представників родини Orchidaceae - для Listera ovata $(\mathrm{RE}=$ 30,15 \%), для Platanthera chlorantha і Epipactis helleborine цей показник не перевищував 15 \%. Досить високі показники репродуктивного зусилля отримали для C. alpina i Pyrola chlorantha, хоча в останнього домінує вегетативне розмноження.

\section{Джерела та література}

1. Багдасарова Т. В. Pyrola sp. / Т. В. Багдасарова, М. Г. Вахрамеева, С. В. Никитина, Л. В. Денисова // Биол. флора Моск. обл. - Т. 7. - М. : МОИП, 1983. - С. 153-176.

2. Блинова И. В. Биология орхидных на северо-востоке Фенноскандии и стратегии их выживания на северной границе распространения : автореф. дис. ... д-ра биол. наук / И. В. Блинова. - М., 2010. - 44 с.

3. Блинова И. В. Индивидуальные стратегии развития орхидных Мурманской области / И. В. Блинова // «Особи и популяции - стратегии жизни». - Ч. 1. - Уфа, 2006 - С. 27-30.

4. Вахрамеева М. Г. Орхидеи нашей страны / М. Г. Вархамеева, Л. В. Денисова, С. В. Никитина, С. К. Самсонов. - М. : Наука, 1991. - 224 с. 
5. Верещагина В. А. Антэкология некоторых верных растений темнохвойного леса / В. А. Верещагина // Ученые записи Перм. гос. ун-та. - 1966. - Т. 130. - С. 19-39.

6. Злобин Ю. А. Популяционная экология растений: современное состояние, точки роста / Ю. А. Злобин. - Сумы : Университет. кн., 2009 - 263 с.

7. Злобин Ю. А. Репродуктивный успех / Ю. А. Злобин // Эмбриология цветковых растений. - Т. 3. СПб. : Мир и семья, 2000. - С. 251-258.

8. Злобин Ю. А. Популяции редких видов растений: теоретические основы и методика изучения : монография / Ю. А. Злобин, В. Г. Скляр, А. А. Клименко. - Сумы : Университет. кн., 2013. - 439 с.

9. Ивашкина Л. А. О состоянии популяций лилии кудреватой в Предуралье / Л. А. Ивашкина // Ботанические исследования на Урале. - 1985. - С. 21-22.

10. Киреев Е. А. Семейство Orchidaceae Juss. в Саратовской области / Е. А. Киреев, О. В. Костецкий // Фиторазнооб. Вост. Европы. - 2006. - № 1. - С. 111-122.

11. Левина Р. Е. Репродуктивная биология семенных растений / Р. Е. Левина. - М. : Наука, $1981-96$ с.

12. Левина Р. Е. Способы распространения плодов и семян / Р. Е. Левина. - М. : МГУ, 1957. - 358 с.

13. Лысякова Н. Ю. Анатомо-морфологические и эмбриологические особенности некоторых видов сем. Orchidaceae Juss. / Н. Ю. Лысякова, Н. Н. Хараим, С. В. Полякова // Ученые записки Тавр. нац. ун-та. Серия : Биология и химия. - 2006. - Т. 19 (58), № 4. - С. 142-150.

14. Муллабаева Э. 3. Некоторые характеристики ценопопуляций Lilium martagon L. На Южном Урале / Э. 3. Муллабаева, А. В. Фатыхова // Вестник Оренбурского гос. ун-та. - 2009. - № 6. - С. 258-260.

15. Немченко Э. П. Лилия кудреватая / Э. П. Немченко // Биологическая флора Московской области. 1993. - T. 9 (1). - C. 32-39.

16. Никитина С. В. Прострел раскрытый / С. В. Никитина, Л. В. Денисова, М. Г. Вахрамеева // Биологическая флора Московской области. - М. : МОИП, 1978. - Т. 4. - С. 79-85.

17. Панченко С. М. Неразрушающие методы морфометрического анализа редких растений и их применение на примере Huperzia selago (Huperziaceae) / С. М. Панченко // Заповідна справа в Україні. 2007. - Т. 13. - Вип. 1-2. - С. 106-110.

18. Собко В. Г. Рідкісні рослини Лівобережного Полісся України / В. Г. Собко, А. П. Лебеда, О. О. Ільєнко. Київ : Фітосоціоцентр, 2006. - 216 с.

19. Стецук Н. П. Биологические особенности и состояние ценопопуляций Epipactis helleborine (L.) Crantz. на территории Южного Приуралья / Н. П. Стецук // Вестник Оренбургского государственного университета, 2008. - № 87. - С. 134-137.

20. Тихонова В. Л. Банк семян / В. Л. Тихонова // Эмбриология цветковых растений. - СПб. : Мир и семья, 2000. - T. 3. - С. 286-298.

21. Фегри К. Основы экологии опыления / К. Фегри, Л. Ван дер Пэйл. - М. : Мир, 1982. - 376 с.

22. Харлампиева М. В. Комплексная характеристика орхидных как объектов Красной книги Брянской области / М. В. Харлампиева // Материалы и доклады Российского Молодежного форума «Экология России и молодежная экологическая політика». - М. : Изд-во Центра охраны дикой природы, 2010. С. $130-132$.

23. Червона книга України. Рослинний світ / ред. Я. П. Дідух. - К. : Глобалконсалтинг, 2009. - 900 с.

24. Graber R. E. Seeds in the original layers and soil of four beech-birch-maple stands / R. E. Graber // Forest Serv. Research paper NE-401. - Broomall, 1978. - 10 p.

25. Harrap A. Orchids of Britain and Ireland / A. Harrap, S. Harrap. - L. : A. and C. Black, 2010. - 481 p.

26. Paling N. British native Orchids: an introduction to their biology and ecology / N. Paling. - L. : CJUK, 2007. - 7 p.

27. Rossi W. Italian Orchids / W. Rossi. - Quad. Cons. Natura, 2002. - 332 p.

28. Vakhrameeva M. G. Orchids of Russia and adjacent countries (within the borders of the former USSR) / M. G. Vakhrameeva, I. V. Tatarenko, T. I. Varlygina, G. K. Torosyan, M. N. Zagulskii. - Lichtenstein : A. R. G. Gantner Verlag, 2008. - 690 p.

Клименко Анна, Коваленко Игорь. Репрдукция как один из факторов устойчивости редких видов растений. Проведены исследования репродукции семи видов редких растений (Epipactis helleborine, Listera ovata, Platanthera chlorantha, Circaea alpine, Lilium martagon, Pulsatilla patens и Pyrola chlorantha) в условиях Национального природного парка «Деснянско-Старогутский». При использовании неразрушающих методов морфометрии исследованиями охвачено более 700 особей. Репродуктивное усилие определяли как отношение количественных показателей к площади листовой поверхности. Установили, что наиболее успешным видом в репродукции оказалась Pulsatilla patens. Репродуктивное усилие данного вида достигало почти 500 \%, ведь Pulsatilla patens размножается преимущественно семенами. Наименьший вклад в репродукцию характерен для Lilium martagon (1,05\%). Среди трех представителей семейства Orchidaceae наибольший вклад в репродукцию 
характерный для Listera ovata $(\mathrm{RE}=30,15$ \%), а для Platanthera chlorantha и Epipactis helleborine данный показатель не превышал 15 \%. Достаточно высокие показатели репродуктивного усилия получили для $C$. alpine и Pyrola chlorantha, хотя у последнего доминирует вегетативное размножение.

Ключевые слова: редкие виды, репродукция, репродуктивное усилие, неразрушающие методы, морфометрия.

Klimenko Anna, Kovalenko Igor. Reproduction as a Factor of the Sustainability of Rare Plant Species. The study of reproduction of seven rare plant species (Epipactis helleborine, Listera ovata, Platanthera chlorantha, Circaea alpine, Lilium martagon, Pulsatilla patens and Pyrolachlorantha) is conducted in the conditions of the National Nature Park "Desniansko-Starogutsky". It covers more than 700 individuals with the use of non-destructive methods of morphometry. Reproductive effort is determined as the ratio of quantitative indicators and leaf-area duration. It has been found out that Pulsatilla patens is the most successful species in reproduction. Reproductive effort of this species reaches almost $500 \%$, because Pulsatilla patens reproduces primarily by seed. Lilium martagon is characterized by the least contribution to reproduction (1,05\%). Among three representatives of the Orchidaceae family, Listera ovata has made the greatest contribution to reproduction (RE is equal to 30,15\%), and in Platanthera chlorantha and Epipactis helleborine this indicator do not exceed $15 \%$. Quite a high level of reproductive effort is observed in C.alpine and Pyrola chlorantha, although the latter is dominated by vegetative reproduction.

Key words: rare species, reproduction, reproductive effort, non-destructive methods, morphometry.

Стаття надійшла до редколегії 17.02.2016 p.

УДК: 635.976 .861

\section{Ірина Скоропляс}

\section{Живцювання троянд на різних субстратах в умовах Кременецького ботанічного саду}

Наведено результати вегетативного розмноження троянд, перспективних для використання в декоративнопромисловому розсадництві. Розглянуто дію регуляторів росту на укорінення зелених живців для прискореного отримання посадкового матеріалу. Установлено, що застосування стимуляторів росту «Корневін» дає кращі результати, порівняно із застосуванням «Епіному» й «Гетероауксину» та контролем при розмноженні троянд зеленими живцями.

Ключові слова: вегетативне розмноження, зелене живцювання, троянда, субстрат.

Постановка наукової проблеми та її значення. Вирощування троянд методом зеленого живцювання відоме давно, але масового впровадження в Україні досі не набуло. Роботу з розмноження кореневласних троянд проводять застарілими методами й вона потребує вдосконалення. Сучасні літературні джерела більше висвітлюють питання розмноження та агротехніки щеплених троянд, які традиційно використовують у декоративному озелененні $[2,4,5,7]$.

Проблеми живцювання й культивування на сучасному рівні кореневласних троянд досліджені менше $[1,3,6]$. Не вистачає новітніх технологій із їх інтенсивного розмноження та культивування в Україні. Тому вдосконалення традиційних, запровадження сучасних технологій виробництва кореневласного садівного матеріалу троянд, добір відповідного асортименту з метою ефективного використання в зеленому будівництві, створення стійких довговічних квітково-декоративних насаджень $є$ дуже актуальними.

Аналіз досліджень цієї проблеми. В основу роботи покладено власні результати визначення впливу регулятора росту «Корневін» на процес укорінення живців троянд ('New dawn', 'Wartburg', 'Vohni majaka', 'Tom tom', 'Zheltos', 'Kent') на базі Кременецького ботанічного саду.

(C) Скоропляс I., 2016 